\title{
12. CENOZOIC PLANKTONIC FORAMINIFERAL BIOSTRATIGRAPHY OF THE SOUTHWESTERN PACIFIC AND TASMAN SEA-DSDP LEG 29
}

\author{
D. Graham Jenkins, Geology Department, University of Canterbury, Christchurch, New Zealand
}

\begin{abstract}
A description is given of the Cenozoic planktonic foraminifera obtained from 10 sites of DSDP Leg 29. The New Zealand Cenozoic planktonic foraminiferal zonal scheme was used with only slight modifications; these are discussed. Brief comments are made on selected taxa.
\end{abstract}

\section{INTRODUCTION}

Drilling operations by Glomar Challenger on Leg 29 of the Deep Sea Drilling Project, undertaken during March-April 1973, yielded 1181 meters of sediment from 16 holes at 10 sites (Figure 1). This report is concerned with the Cenozoic planktonic foraminifera obtained from the sites, with emphasis on the biostratigraphic zonation, and a comparison of some of the taxa with records published in Australia and New Zealand. An account of the planktonic foraminifera for each site is given in the Site Report chapters (this volume).

This study of samples was undertaken for the following purposes; (a) determination of the total planktonic foraminiferal fauna; (b) age resolution of the samples into the established New Zealand zonal scheme; and (c) accurate resolution of zonal boundaries.

\section{Procedures}

Samples were washed on a 230-mesh sieve, dried, and sieved into fine, medium, and coarse fractions. Normal-

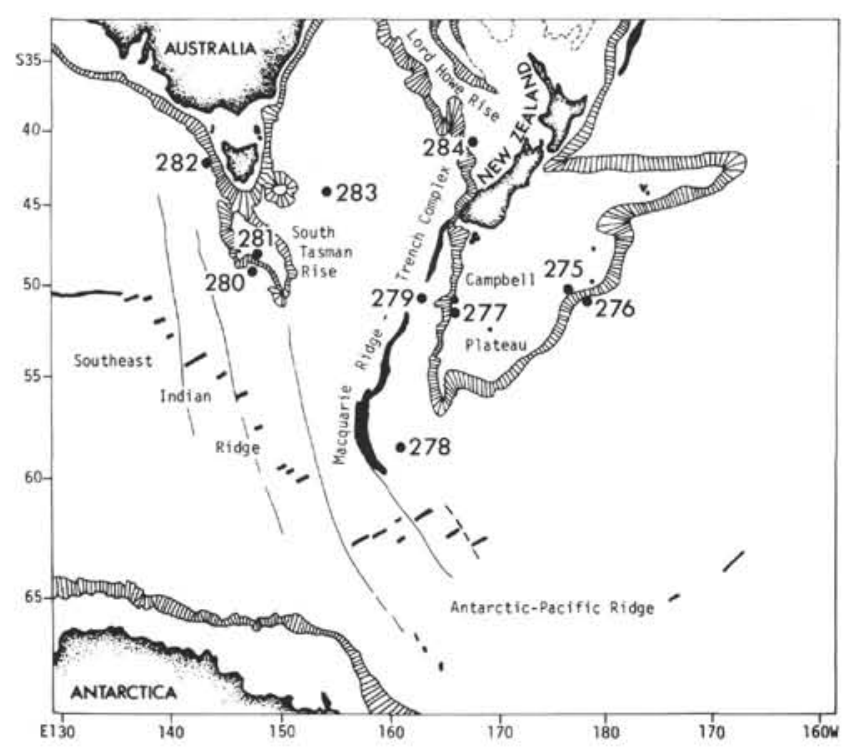

Figure 1, Location of sites drilled during DSDP Leg 29. ly, each core-catcher sample was examined. In order to determine the positions of the zonal boundaries, examination was also made of numerous intermediate samples until the boundary was resolved between the closest two samples. Two samples per core section were taken for examination to position the zonal boundaries. Once a boundary had been determined, only the faunas from the two samples approximating the boundary were normally recorded in addition to the core-catcher samples (Tables 1-6).

Most of the taxa encountered on Leg 29 have previously been recorded and illustrated from Australia (Jenkins, 1966) and New Zealand (Jenkins, 1971).

\section{ZONAL SCHEME}

It was apparent before Leg 29 began that the New Zealand Cenozoic planktonic foraminiferal zonal scheme would probably be workable to the south of New Zealand. The problem remained as to how far south the scheme would work before the faunas became radically changed. This working hypothesis remained true for all sites except at the southernmost Site 278 at $55^{\circ} 33^{\prime} \mathrm{S}$. Unfortunately the water depth at Site 278 was so great during the Oligocene-Pleistocene, compared with the present depth of 3698 meters, that most of the planktonic foraminiferal tests had probably gone into solution. Thus, Site 278, because of extreme water depth, is not regarded as a true test for the zonal scheme at this latitude, and because of the dissolution of tests, three informal zones were used to cover the upper Oligocene-Miocene interval. These were based on the few solution-resistant taxa. The three informal zones, in ascending order, which were devised for Site 278 are: Globigerina (G.) woodi, Globorotalia (T.) conica, and Globigerina (G.) bulloides (Table 7).

The zonal scheme used on Leg 29 was based mainly on previous work by the writer in Australia and New Zealand. The middle Oligocene-upper Miocene sequence of the Lakes Entrance oil shaft, Victoria, Australia, was sub-divided into 11 zones (Jenkins, 1960). Most of these zones were incorporated into a subdivision of the New Zealand Cenozoic into 21 zones (Jenkins, 1966, 1967). The main addition to the Cenozoic zonal scheme has been the subdivision (in ascending order) of the Pliocene-Pleistocene $G$. (T.) inflata Zone into the $G$. (T.) puncticulata, $G$. (T.) inflata, and $G$. (G.) 
D. G. JENKINS

TABLE 1

Ranges of Planktonic Foraminifera in Selected Samples of Site 277

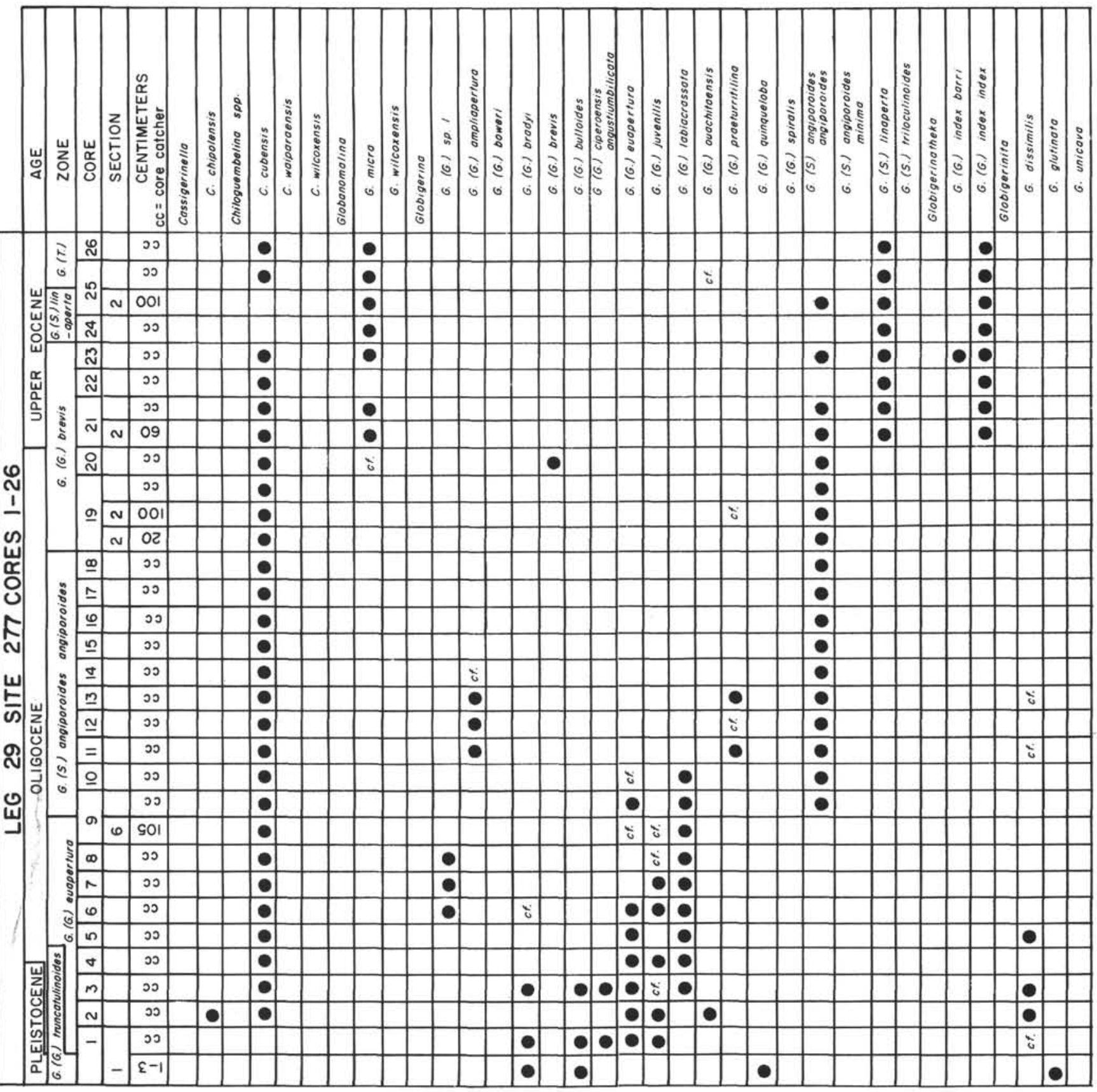


TABLE 1 - Continued

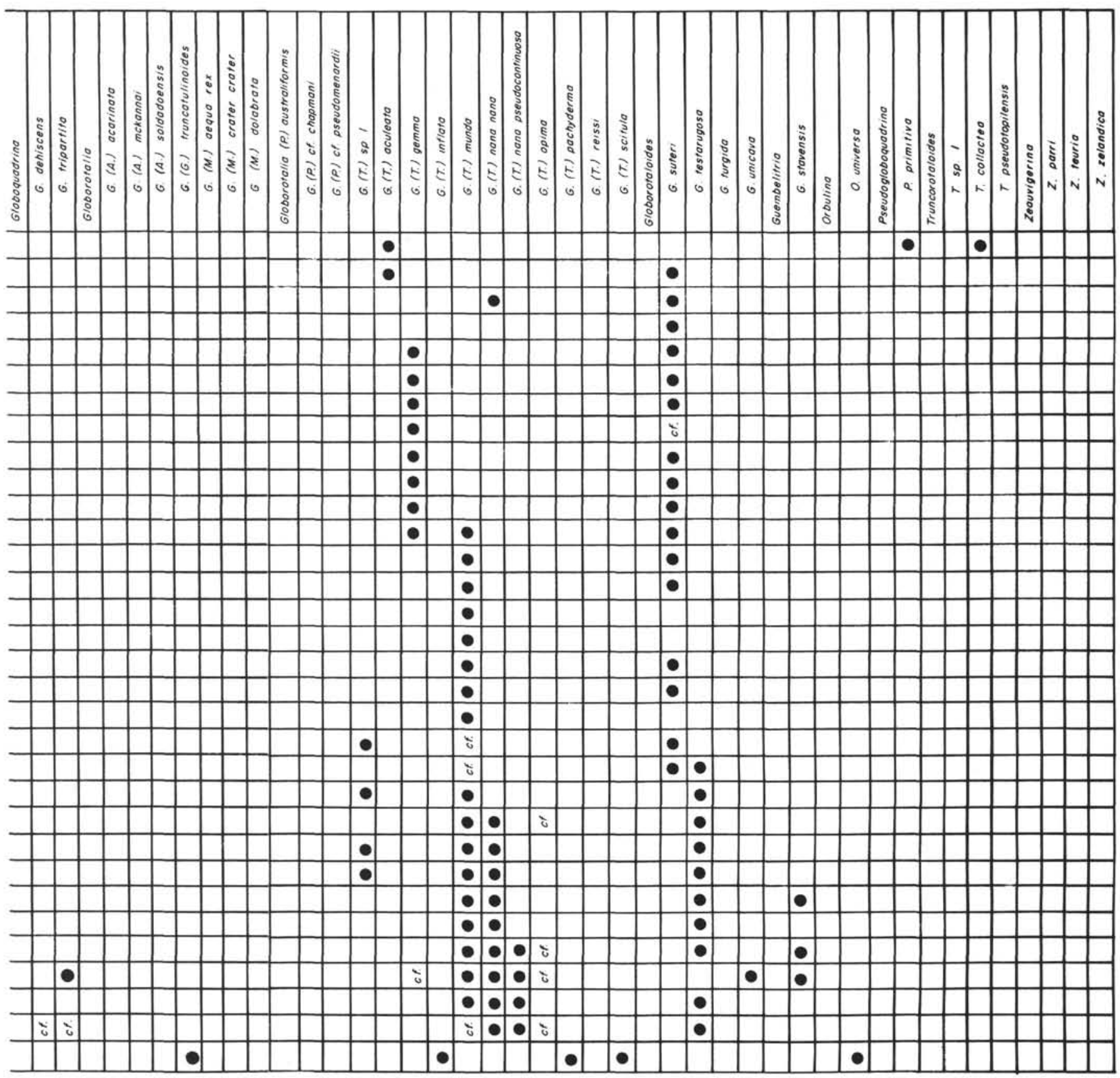


TABLE 1 - Continued

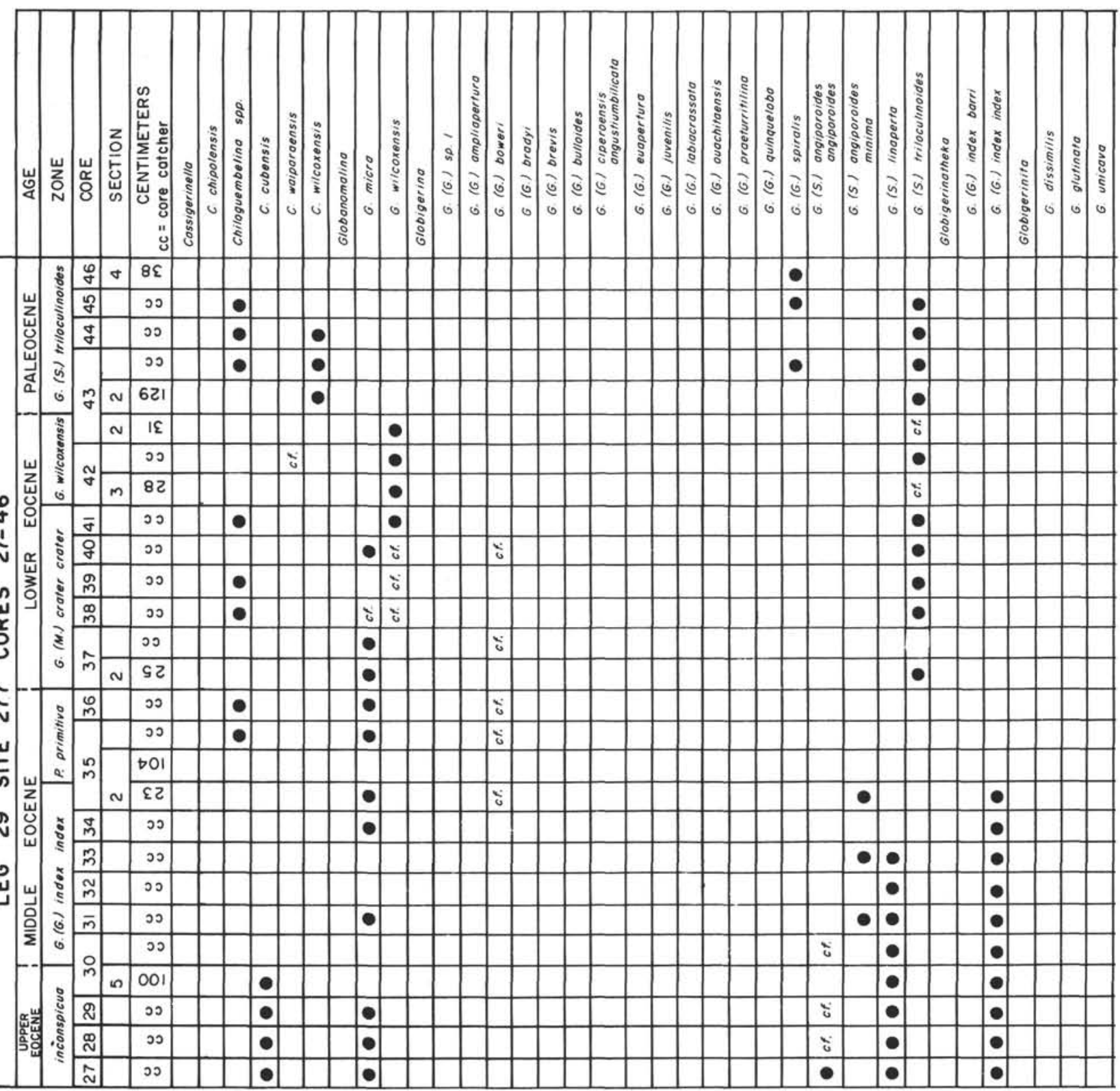


TABLE 1 - Continued

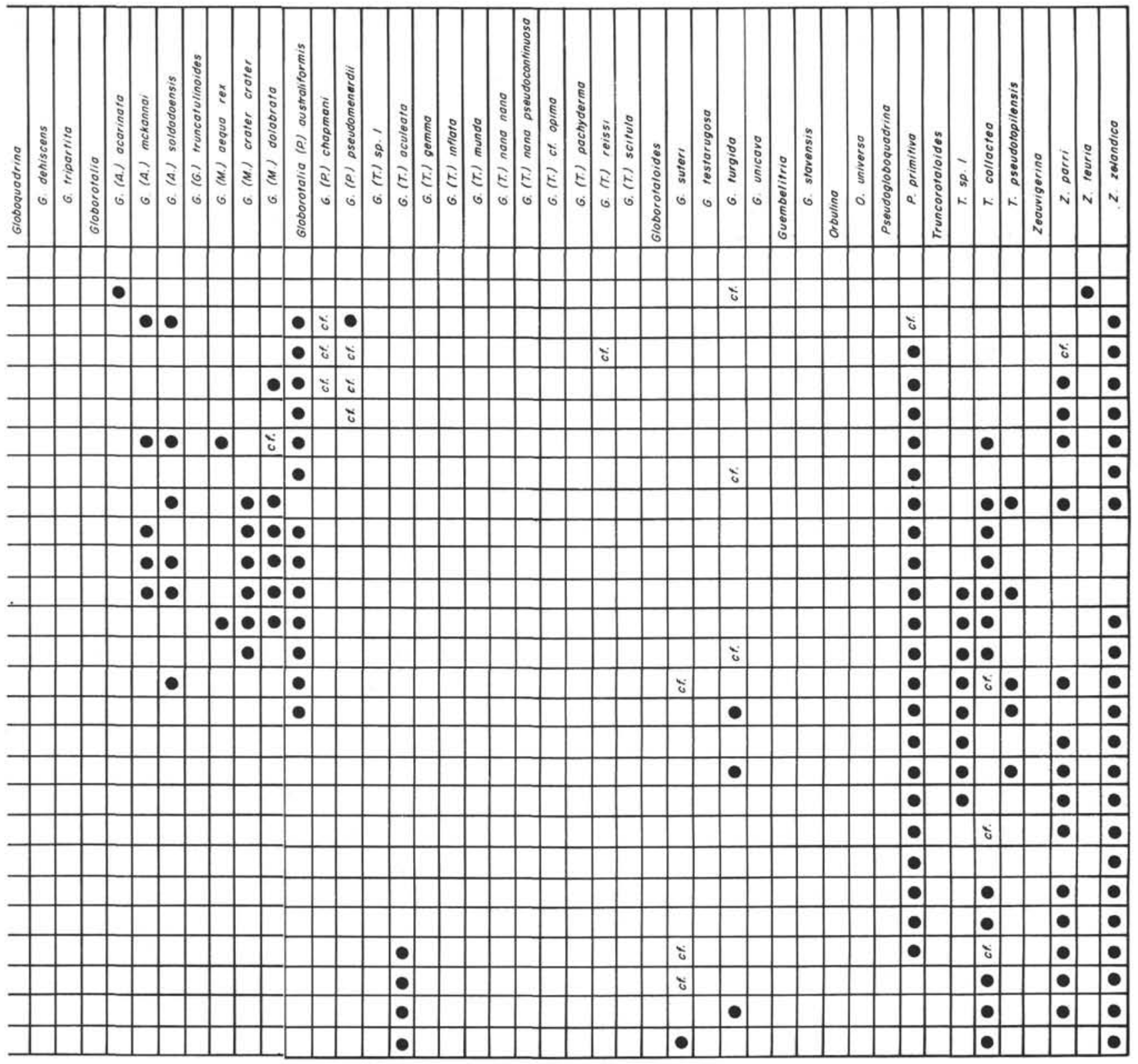


TABLE 2

Ranges of Planktonic Foraminifera in Selected Samples of Site 278

\begin{tabular}{|c|c|c|c|c|c|c|c|c|c|c|c|c|c|c|c|c|c|c|c|c|c|c|c|c|c|c|c|c|}
\hline & & & & LE & $E G$ & २ & 9 & & SIT & ES & & & 78 &, 2 & 78 & BA & & $\mathrm{CC}$ & DR & ES & & 1- & 34 & & & & & \\
\hline $\mathrm{PL}$ & EIST & $\mathrm{TOCP}$ & EN & & PLI & $10 \mathrm{C}$ & ENE & & & 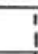 & & & & & & & $110 \mathrm{C}$ & EEN & & & & & & & ? & $\mathrm{OLI}$ & GOCENE & AGE \\
\hline Gic & $\begin{array}{l}\text { G) tru } \\
\text { poides }\end{array}$ & unca- & & $\begin{array}{l}\text { GT, } \\
\text { inflat }\end{array}$ & & G $\& T$ & oun & neticu & Jlato & & & (6.) 0 & bullori & & & & (T.) ac & inico & & & & 6. 16 & I wo & & $\begin{array}{r}6.75 \\
\text { of } \\
\end{array}$ & $\begin{array}{l}\text { Ton } \\
\text { ggipo }\end{array}$ & $\begin{array}{l}\text { griporoides } \\
\text { oroides }\end{array}$ & ZONE \\
\hline 1 & |A & $2 A$ & 1 & 2 & 3 & 4 & 5 & 6 & 7 & 8 & 9 & 10 & 11 & 12 & 13 & 17 & 18 & 19 & 20 & 21 & 22 & 23 & 252 & $26 \sqrt{3}$ & 313 & 23 & 3334 & CORE \\
\hline 1 & & & & & & & & & & & & & & & & & & & & & & & & & & & 3 & SECTION \\
\hline - & & & 은 & : & : & : & 0 & : & $:$ & : & $\because$ & : & : & 0 & : & : & 0 & ن & : & $\ddot{0}$ & 0 & : & i & $:$ & $:$ & 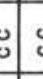 & \begin{tabular}{l|l|}
$ن$ & $\infty$ \\
\end{tabular} & $\begin{array}{l}\text { CENTIMETERS } \\
C C=\text { core cotcher }\end{array}$ \\
\hline & & & & & & & & & & & & & & & & & & & & & & & & & & & & Globigerina \\
\hline$\bullet$ & - & & & & - & & & & & & & 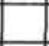 & & & & & & & & & & & & & & & & G. (G.) bradyi \\
\hline 누 & $\theta$ & - & ? & & - & & & & $\bullet$ & & - & - & - & - & - & & & & & $c f$ & & & & & & & & G. (G) bulloides \\
\hline & & & & & & & & & & & & & & & & & & & & & & & & & & 6 & 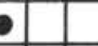 & G. (G) ciperoensis angustiumbilicato \\
\hline & & & & & & & & & & & & & & & & & & & & & & & & 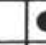 & 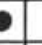 & & & G. (G.) juvenilis \\
\hline - & - & & & & - & & & & & & & & & & & & & & & & & & & & & & & G. (G.) quinquelobo \\
\hline & & & & & & & & & & & & & & & & - & - & - & - & - & & & - & 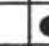 & a & f. & ? & G. (G.) woodi woodi \\
\hline & & & & & & & & & & & & & & & & & & & & & & & & & & & - & G. (5.) angiporoides angiporoides \\
\hline & & & & & & & & & & & & & & & & & & & & - & - & - & c. & ef. $\quad$ c & . & & & Globigerinito dissimilis \\
\hline & - & & & & & & & & & & & & & & & & & & & & & & & 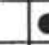 & 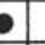 & & & 6. glutinato \\
\hline & & & & & & & & & & & & & & & & & & & & & & & & & & & & Globorotalio \\
\hline - & & & & & & & & & & & & & & & & & & & & & & & & & & & & G. (G.) truncotulinoides \\
\hline & & & & & & & & & & & & & & & & - & & & 은 & & & & & & & & & G. $(T)$ conico \\
\hline & - & 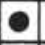 & & & & & & & & & & & & & & & & & & & & & & & & & & G. $(T)$ intiata \\
\hline & & & & & & & & & & & & & & & & & & & & & & & & & $c$ & & & G. $(T$.$) nano nana$ \\
\hline & & & & & & & & & & & & & & & & & & & & ? & & & & & & & & G. (T.) nana pseudocontinuosa \\
\hline - & - & & - & - & - & ? & - & - & - & ? & 은 & & & & & & & & & & & & & & & & & G. (T) pachyderma \\
\hline & & & & & - & & & - & & - & cf. & & & & & & & & & & & & & & & & & $G(T)$ puncticulato \\
\hline & & & & & & $\bullet$ & & & & & & & & & & & & & & & & & & & & & & G. $(T)$ scitula \\
\hline
\end{tabular}

truncatulinoides zones; these zones have been used informally by the writer in New Zealand (Table 7). The taxa used to delineate the zonal boundaries are shown in Table 8; the zones penetrated at the various sites are shown in Table 9.

The lack of certain taxa and paucity of others made it necessary to make a few minor amendments to the New Zealand zonal scheme:

1) Because of the total absence of Globorotalia (T.) inconspicua at Site 277, it was decided to follow the precedent of micropaleontologists from South Australia (Ludbrook and Lindsay, 1969), and refer the zone as Globorotalia (T.) aculeata Zone.

2) Globigerina (G.) brevis was found to be very rarre at Site 277 and absent at Site 282. This led to the redefinition of the zone based on the total range of Globorotalia (T.) gemma which has the same range as $G$. (G.) brevis in New Zealand (Jenkins, 1966).

\section{SYSTEMATIC PALEONTOLOGY}

\section{Cassigerinella chipolensis (Cushman and Ponton)}

C. chipolensis was found to be very rare, and was only recorded in the $G$. (G.) euapertura Zone at Site 277. In New Zealand $C$. chipolensis occurs as far south as the Clifden section at about $46^{\circ} \mathrm{S}$ (Jenkins, 1971).

\section{Chiloguembelina cubensis (Palmer)}

C. cubensis was found generally in abundance in samples at Site 277 from the $G$. $(T$.) aculeata Zone to the lower $G$. (G.) euapertura Zone. C. cubensis is less abundant at its lower stratigraphic range.

\section{C. wilcoxensis (Cushman and Ponton)}

At Site 277 C. wilcoxensis was found to be a useful marker in the Paleocene G. (S.) triloculinoides Zone.

\section{Globanomalina micra (Cole)}

Specimens of G. micra were obtained at Site 277 from the lower part of the $G$. (M.) crater crater Zone to about the middle of the $G$. (G.) brevis Zone. G. micra was found to be very rare towards the upper Eocene-lower Oligocene.

\section{G. wilcoxensis (Cushman and Ponton)}

A few specimens of $G$. wilcoxensis were obtained from the $G$. wilcoxensis Zone, with transitional forms linking it to $G$. micra in the $G$. (M.) crater crater Zone.

\section{Globigerina (G.) ciperoensis angustiumbilicata Bolli}

Very rare specimens were found at Sites 277,279 , and 281 , but were a little more common at Site 282 . It is probable that its rarity in the southern sites was due to temperature control.

\section{G. (G.) bradyi Weisner}

G. (G.) bradyi was found to be fairly common at some sites such as 279 and 284 , but rare at other sites. 


\section{G. (G.) bulloides d'Orbigny}

G. (G.) bulloides was common at most sites examined and seems to have a relatively solution-resistant test at Site 278 . It is fairly common at Site 279 where it seems to replace $G$. (G.) woodi woodi in the middle Miocene as the most common Globigerina within their size range.

\section{G. (G.) eamesi Blow}

The occurrence of $G$. (G.) eamesi at sites of Leg 29 is sporadic: absent at Sites 277 and 278; very rare at Sites 279 and 282; and fairly common in the $G$. trilobus trilobus- $G$. (G.) woodi connecta zones at Site 281. This distribution is hardly explained by assuming a temperature control, but, within its stratigraphic range, it is fairly common in continental shelf deposits in New Zealand.

\section{G. (G.) labiacrassata Jenkins}

At Site 277, G. (G.) labiacrassata found in the $G$. (S.) angiporoides angiporoides-G. (G.) euapertura zones resembles $G$. (G.) woodi woodi, but has a thicker apertural lip, and has less coarse wall ornamentation. A few specimens found at Site 282 in faunas of low diversity suggests that $G$. (G.) labiacrassata has a relatively solution-resistant test.

\section{G. (G.) nepenthes Todd}

It is probable that the paleogeographic distribution of $G$. (G.) nepenthes was temperature controlled. During Leg 29 it was found in only one sample from Site 282 and one doubtful specimen from Site 284. It is therefore concluded that sites drilled on Leg 29 were south of its original distribution.

\section{G. (G.) ouachitaensis Howe and Wallace}

G. (G.) ouachitaensis has a sporadic distribution in the area drilled: one specimen occurred in the G. (G.) euapertura Zone at Site 277; one specimen in the $G$. (G.) woodi connecta Zone at Site 279; and a few specimens in the $G$. (G.) brevis- $G$. (S.) angiporoides angiporoides zones at Site 282.

\section{G. (G.) quinqueloba Natland}

As expected from its Recent distribution, G. (G.) quinqueloba was found to be common in the Miocene-Pleistocene at Sites 279, 281, and 284.

\section{G. (G.) woodi connecta Jenkins}

Most of the specimens in the G. trilobus trilobus Zone at Site 279 are thick walled and approach the morphology of Sphaeroidinella cellata Subbotina. Also at Site 279 G. (G.) woodi connecta ranges into the upper part of G. trilobus trilobus Zone, well above its recorded range in New Zealand (Jenkins, 1971).

\section{G. (G.) woodi woodi Jenkins}

Well-preserved specimens of $G$. (G.) woodi woodi were obtained from the upper Oligocene-Miocene of Site 278 in a low-diversity fauna which had probably been caused by selective solution of tests. At Site $279 G$. (G.) woodi woodi is well-developed in the lower Miocene with some of the thick-walled specimens resembling Sphaeroidinella cellata Subbotina. Also at Site 279 it is the commonest Globigerina in the $G$. (G.) woodi connecta-G. trilobus trilobus zones, but is replaced by $G$. (G.) bulloides as the dominant form in the middle Miocene. A similar change in dominance was also noted at Site 281 .

\section{G. (G.) woodi decoraperta Takayanagi and Saito}

$G$. (G.) woodi decoraperta was found to be rare in the $G$. (T.) mayeri mayeri Zone at Site 279; one was recorded in the $G$. (G.) miotumida miotumida Zone at Site 282. It was found to be much more common in the lower latitude Site $284\left(40^{\circ} 30^{\prime} \mathrm{S}\right)$ in the $G$. (G.) miotumida miotumida-G. (T.) inflata zones.

\section{G. (S.) angiporoides angiporoides Hornibrook}

Within its upper Eocene-middle Oligocene stratigraphic range $G$. (S.) angiporoides angiporoides is fairly common at Sites $277,278,281$, and 282. It appears to have had a solution-resistant test.

\section{G. (S.) linaperta Finlay}

G. (S.) linaperta is present in the middle upper Eocene at Site 277. From its presence in the upper Eocene of Sites 281 and 282 it is postulated that it has a tough solution-resistant test.

\section{G. (S.) triloculinoides Plummer}

It is quite common within its stratigraphic range of $G$. (S.) triloculinoides-G. (M.) crater crater zones at Site 277.

Globoquadrina altispira (Cushman and Jarvis)

A few specimens were found in the $G$. (G.) miozea conomiozea and G. (T.) inflata zones at Site 284.

\section{G. dehiscens (Chapman, Parr, and Collins)}

Within the $G$. (G.) woodi connecta to $G$. (T.) mayeri mayeri zones at Site $279, G$. dehiscens is fairly common, but the tests appear to be less quadrate than usual in New Zealand. At Site 282 it was also fairly common in the $G$. (G.) woodi woodi-G. (G.) miotumida miotumida zones. It is noteworthy that $G$. dehiscens was not recorded in the upper Miocene-Pliocene of Site 284

\section{G. tripartita (Koch)}

From its paleogeographic distribution in New Zealand it has been assumed that $G$. tripartita was a warm-water form. If this postulate is true, then its occurrence in the $G$. (G.) woodi connecta-G. trilobus trilobus zones at Site 279 could indicate warmer water conditions.

\section{Globigerinatheka (G.) index index (Finlay)}

The stratigraphically lowest, rare specimens in the $G$. (G.) index index Zone at Site 277 resemble New Zealand specimens of this zone, with only one aperture. Thereafter in the zone, it became more common with specimens having multiple apertures.

Deduced from its occurrence in upper Eocene sediments at Site 282, $G$. (G.) index index appears to have had a robust, solution-resistant test.

\section{Globigerinella aequilateralis (Brady)}

It occurs sporadically at Site 281 , south of the subtropical convergence, in the $G$. (T.) puncticulata-G. (G.) truncatulinoides interval. The occurrence of $G$. aequilateralis at Site 281 without warmwater forms such as Globigerinoides tends to suggest that it is more tolerant of cooler water than the latter genus. Well within the subtropical belt at Site $284, G$. aequilateralis is common in the $G$. (G.) miotumida miotumida- $G$. (G.) truncatulinoides zones.

\section{Globigerinita dissimilis (Cushman and Bermudez)}

G. dissimilis is rare in the G. (G.) euapertura Zone at Site 277, and in the $G$. (G.) woodi woodi Zone at Site 278 . At both sites 279 and $281, G$. dissimilis appears to have become extinct later than in New Zealand. This extinction is before the initial appearance of $G$. $(G$.) miozea miozea. Some of the specimens in the $G$. (G.) woodi connecta Zone at Site 279 have exceptionally thick tests, and its general occurrence at other sites suggests that it has a solution-resistant test.

\section{Globigerinoides altiaperturus Bolli}

At Sites 279 and 281 it is not present within its known lower Miocene New Zealand range of $G$. $(G$.) woodi connecta-G. trilobus trilobus zones, but there is one specimen in the $G$. (G.) woodi connecta Zone at the more northerly Site 282. It is concluded that its original paleogeographic distribution was probably temperature controlled.

\section{G. trilobus bisphericus Todd}

A few doubtful specimens of $G$. trilobus bisphericus were recorded at Site 279 in the G. trilobus trilobus Zone, but it was not present within its known range at Site 281 .

\section{G. ruber (d'Orbigny)}

A single, doubtful, specimen was recorded in the $G$. (T.) mayeri mayeri Zone at Site 279. Rare specimens are present in the $G$. (G.) truncatulinoides Zone at Site 282, and it is fairly common in the $G$. (G.) miozea conomiozea-G. (G.) truncatulinoides zones at Site 284. 
TABLE 3

Ranges of Planktonic Foraminifera in Selected Samples of Site 279

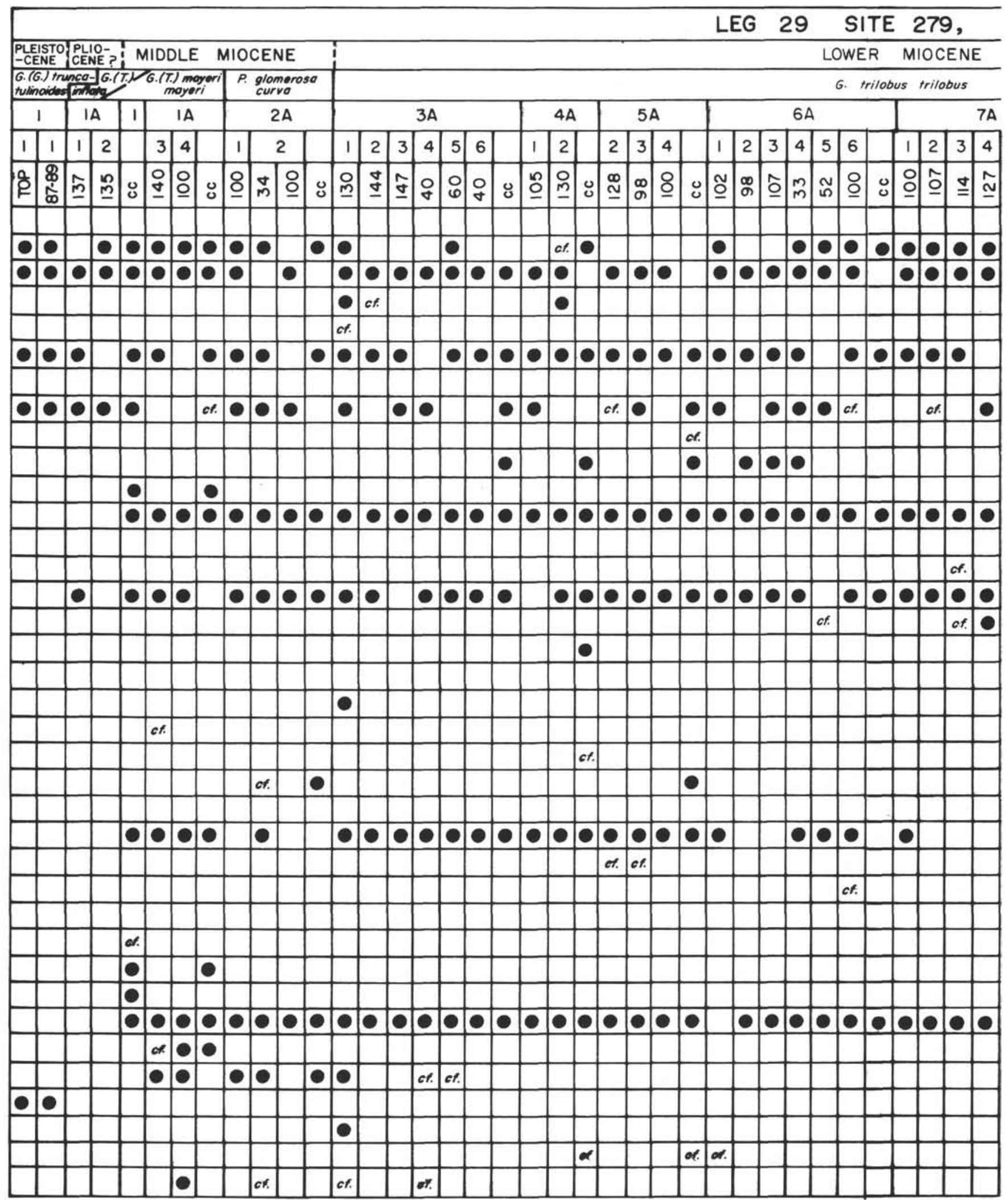


TABLE 3 - Continued

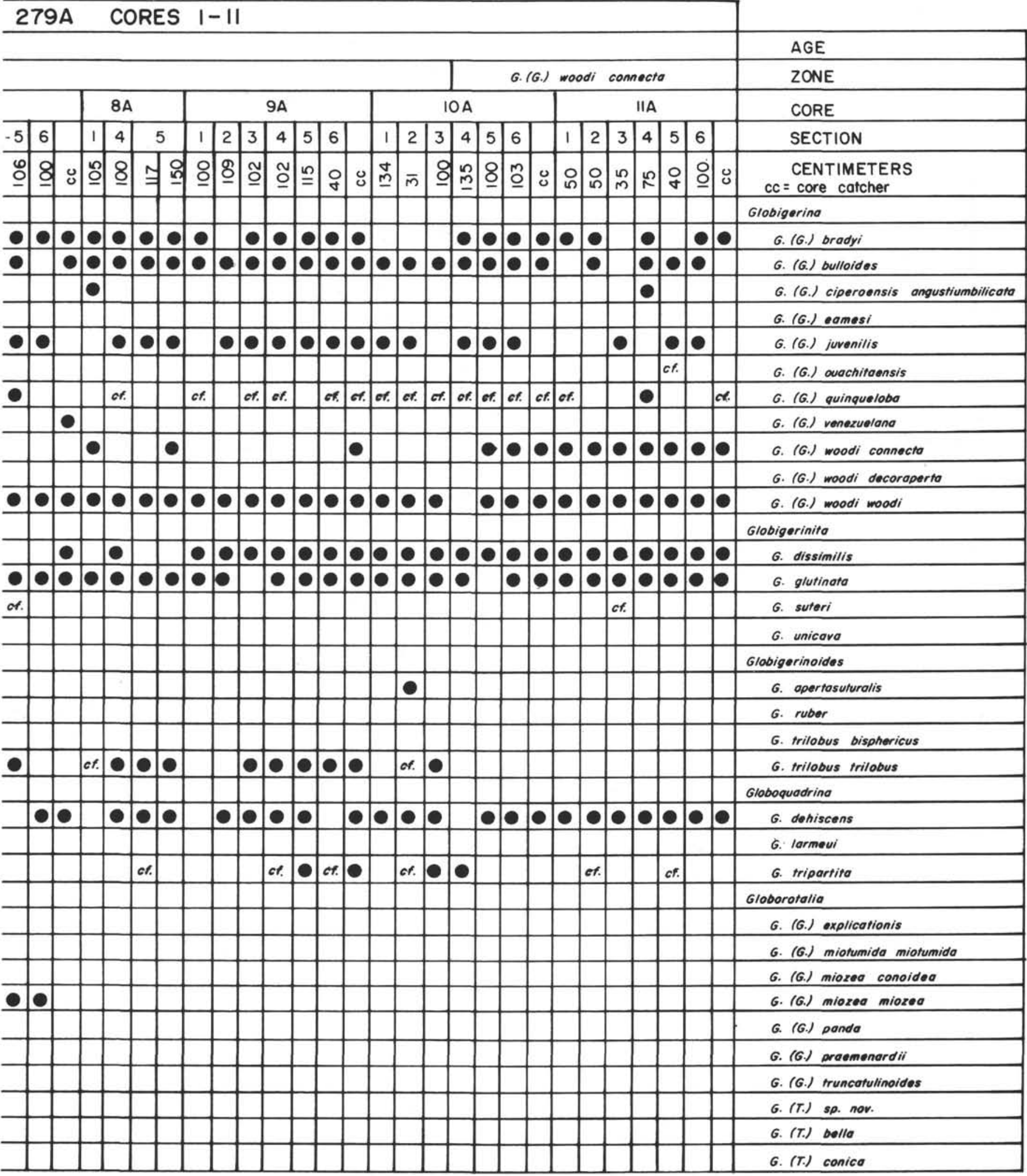


TABLE 3 - Continued

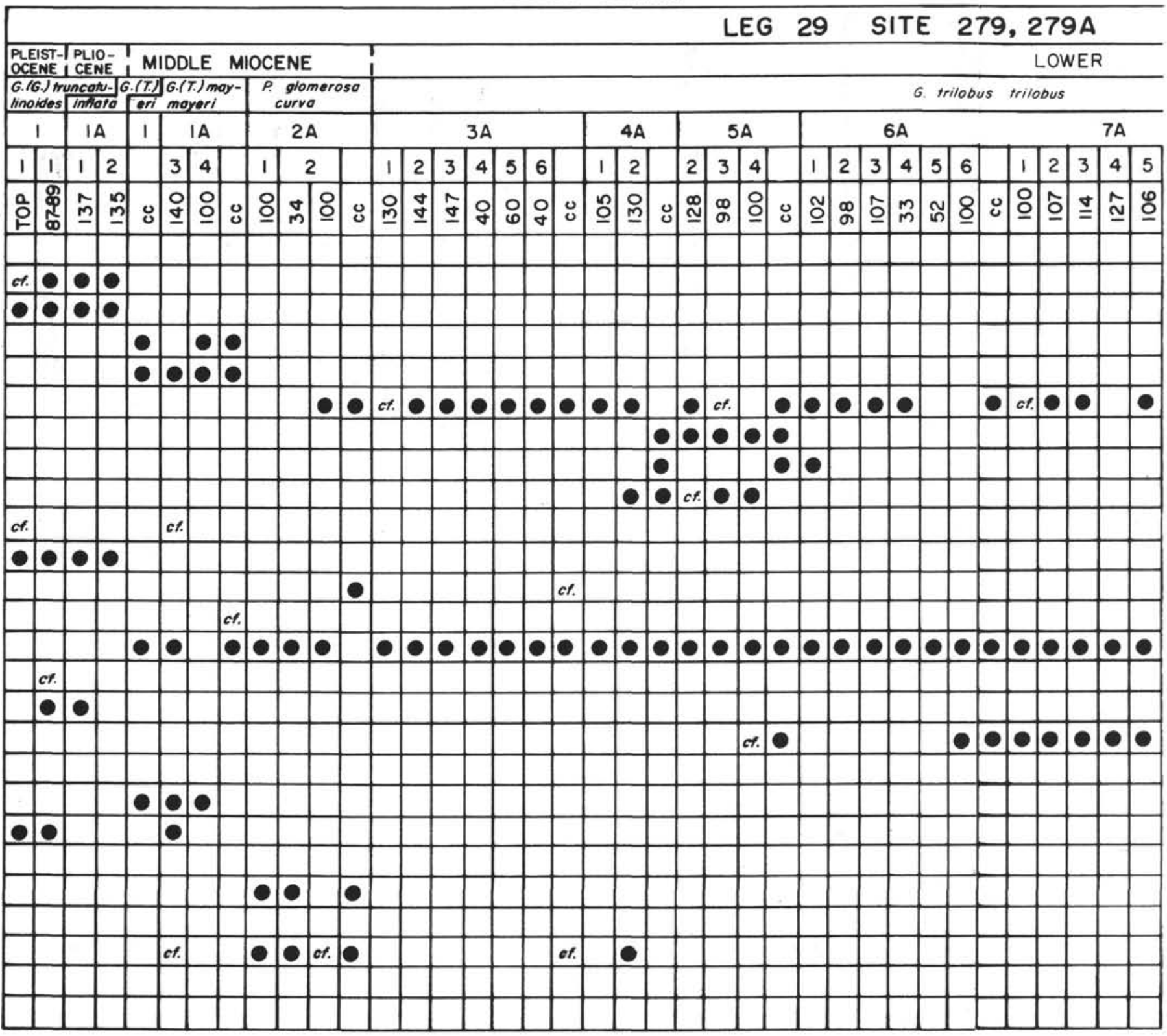

\section{G. trilobus trilobus (Reuss)}

Generally, G. trilobus trilobus was found to be rare within the drilled area, but was commonest within its zone at Site 279 .

\section{Globorotalia (G.) miotumida explicationis Jenkins}

It is very well developed in the $G$. (G.) miotumida miotumida Zone and lower part of the G. (G.) miozea conomiozea Zone at Site 284. In New Zealand, $G$. (G.) miotumida explicationis has been recorded from the top of the $G$. (T.) mayeri mayeri Zone to the top of the $G$. (G.) miotumida miotumida Zone (Jenkins, 1971).

\section{G. (G.) miotumida miotumida Jenkins}

At Site 284 it has a range from the $G$. (G.) miotumida miotumida Zone to the lower part of the $G$. (T.) puncticulata Zone. This is very similar to its range in New Zealand (Jenkins, 1971).

\section{G. (G.) miozea conomiozea Kennett}

There appears to be a transition in morphology between it and $G$. (G.) miotumida miotumida at Site 284 in Sample 284-17, CC.

\section{G (G.) miozea miozea Finlay}

It is fairly common in the $G$. (T.) mayeri mayeri Zone at Site 279 where the populations are sinistrally coiled and specimens are thick walled. The evolutionary change from $G$. (T.) praescitula to $G$. (G.) miozea miozea may have occurred earlier at Site 279 compared to the transition in New Zealand. Consideration should be given to the possibility that $G$. (G.) miozea miozea is a deep-water ecophenotype and may therefore appear earlier in deep water deposits compared to the continental shelf deposits of New Zealand.

\section{G. (G.) panda Jenkins}

Rare specimens occur in the G. (T.) mayeri mayeri Zone at Site 279. 
TABLE 3 - Continued

\begin{tabular}{|c|c|c|c|c|c|c|c|c|c|c|c|c|c|c|c|c|c|c|c|c|c|c|c|c|c|c|c|}
\hline \multirow{2}{*}{\multicolumn{27}{|c|}{$\begin{array}{l}\text { CORES } 1- \\
\text { MIOCENE }\end{array}$}} & \multirow{3}{*}{ AGE } \\
\hline & & & & & & & & & & & & & & & & & & & & & & & & & & & \\
\hline & & & & & & & & & & & & & & & & \multicolumn{11}{|c|}{ G. (G.) woodi connecto } & \\
\hline & & \multicolumn{4}{|c|}{ BA } & \multicolumn{7}{|c|}{$9 A$} & \multicolumn{7}{|c|}{ IOA } & \multicolumn{7}{|c|}{$\| \mathrm{A}$} & CORE \\
\hline 6 & & 1 & 4 & 5 & & 1 & 2 & 3 & 4 & 5 & 6 & & 1 & 2 & 3 & 4 & 5 & 6 & & 1 & 2 & 3 & 4 & 5 & 6 & & SECTION \\
\hline \multirow[t]{6}{*}{ 으 } & : & 으 & 으 & $\stackrel{ }{=}$ & 음 & 으 & 으 & 으 & 으 & $\stackrel{n}{=}$ & 이 & 0 & $\underline{m}$ & $\bar{m}$ & 으 & $\underline{m}$ & 으 & 으 & 0 & 우 & 임 & $m$ & 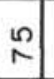 & 이 & 으 & 0 & $\begin{array}{l}\text { CENTIMETERS } \\
c c=\text { core catcher }\end{array}$ \\
\hline & & & & & & & & & & & & & & & & & & & & & & & & & & & Globorotalia \\
\hline & & & & & & & & & & & & & & & & & & & & & & & & & & & G. (T.) crassaformis \\
\hline & & & & & & & & & & & & & & & & & & & & & & & & & & & G. (T.) inflato \\
\hline & & & & & & & & & & & & & & & & & & & & & & & & & & & G. $(T$.) mayeri continuosa \\
\hline & & & & & & & & & & & & & & & & & & & & & & & & & . & & G. (T.) mayeri mayeri \\
\hline ㄴ. & - & - & - & - & - & 은 & - & - & & - & - & of. & & & - & - & - & - & - & cf. & & & cf. & - & - & & G. $(T$.$) minutissima$ \\
\hline \multirow[t]{7}{*}{ 오 } & & - & 은 & 이 & 인 & ? & - & - & - & - & & & - & & - & - & - & - & - & - & 이 & - & - & - & 리 & - & G. (T.) nana pseudocontinuosa \\
\hline & & & & & & & & & - & & & - & - & ? & & & & & & of. & & & & & . & 0 & G. (T.) nana nana \\
\hline & & & & & & & & & & cf. & - & - & & ? & - & - & & - & & & - & & & & - & & G. (T.) nano semivera \\
\hline & & & & & & & & & & & & & & & & & & & & & & & & & & & G. (T.) obesa \\
\hline & & & & & & & & & & & & & & & & & & & & & & & & & & & G. (T.) pachyderma \\
\hline & & & & & & & & & & & & & & & & & & & & & & & & & & & G. (T.) peripheroronda \\
\hline & & & & & & & & & & & & & & & & & & & & & & & & & & & G. (T.) proefohsi \\
\hline \multirow[t]{3}{*}{ 이 } & - & - & ? & ? & - & - & - & - & - & - & - & 0 & - & 0 & - & 0 & - & - & - & & & & - & & & & G. (T.) praescitula \\
\hline & & & & & & & & & & & & & & & & & & & & & & & & & & & G. (T.) puncticulata \\
\hline & & & & & & & & & & & & & & & & & & & & & & & & & & & G. (T.) scitula \\
\hline \multirow[t]{10}{*}{ 으 } & 은 & - & - & - & - & - & - & - & - & - & - & - & & & cf. & & & & & & & & & & & & G. (T.) zealandica \\
\hline & & & & & & & & & & & & & & & & & & & & & & & & & & & Oroulina \\
\hline & & & & & & & & & & & & & & & & & & & & & & & & & & & O. suturalis \\
\hline & & & & & & & & & & & & & & & & & & & & & & & & & & & 0. universa \\
\hline & & & & & & & & & & & & & & & & & & & & & & & & & & & Praeorbulina \\
\hline & & & & & & & & & & & & & & & & & & & & & & & & & & & P. glomerosa curva \\
\hline & & & & & & & & & & & & & & & & & & & & & & & & & & & Sphaeroidinello \\
\hline & & & & & - & & & & & & & & & cf. & & & & & cf. & & & & of. & & & & S. disjuncta \\
\hline & & & & & & & & & & & & & & & & & & & & & & & & & & & Turborotalito \\
\hline & & & & & & 2) & & & & & & & & & & & & & & & & & & & & & T. sp. nov. \\
\hline
\end{tabular}

\section{G. (G.) truncatulinoides (d'Orbigny)}

Various morphological forms were found at the sites drilled on Leg 29 including morphotypes of $G$. (T.) tosaensis at Sites 275 and 284 Well-developed, keeled, sinistrally coiled specimens of $G$. $(G$. truncatulinoides were found at Sites 280, 281, 282, and 284.

\section{G. (M.) crater crater Finlay}

Typical forms were found in its zone at Site 277, but the populations did not yield $G$. (M.) crater caucasica Glaessner with 6-7 chambers in the final whorl, which is found in New Zealand (Jenkins, 1971).

\section{G. (T.) aculeata Jenkins}

$G$. (T.) aculeata was found to be fairly common within its upper Eocene range at Site 277 where it appears to have had a later extinction, compared with this event in New Zealand (Jenkins, 1971).

\section{G. (T.) conica Jenkins}

It is much better developed at Sites 278, 279, and 281 compared with its records in Australia (Jenkins, 1960) and New Zealand (Jenkins,
1971). It is postulated that $G$. (T.) conica was possibly a cooler water taxon which made brief incursions into the Australian and New Zealand waters during the middle Miocene.

\section{G. (T.) crassaformis (Galloway and Wissler)}

Large specimens of $G$. (T.) crassaformis were obtained in Pleistocene-Recent sediments from Sites 279 and 284; some from Site 284 have well-developed keels.

\section{G. (T.) gemma Jenkins}

At Sites 277 and 282, G. (T.) gemma has been used as a zonal marker for the $G$. (G.) brevis Zone. There is evidence in the samples from Site 282 that $G$. (T.) gemma had a solution-resistant test.

\section{G. (T.) inflata (d'Orbigny)}

It normally formed a dominant part of the Pliocene(?)-Pleistocene planktonic foraminiferal faunas at most sites. $G$. (T.) inflata, the only species present at Site 283, appears to have a solution-resistant test. 
TABLE 4A

Ranges of Planktonic Foraminifera in Selected Samples of Site 281

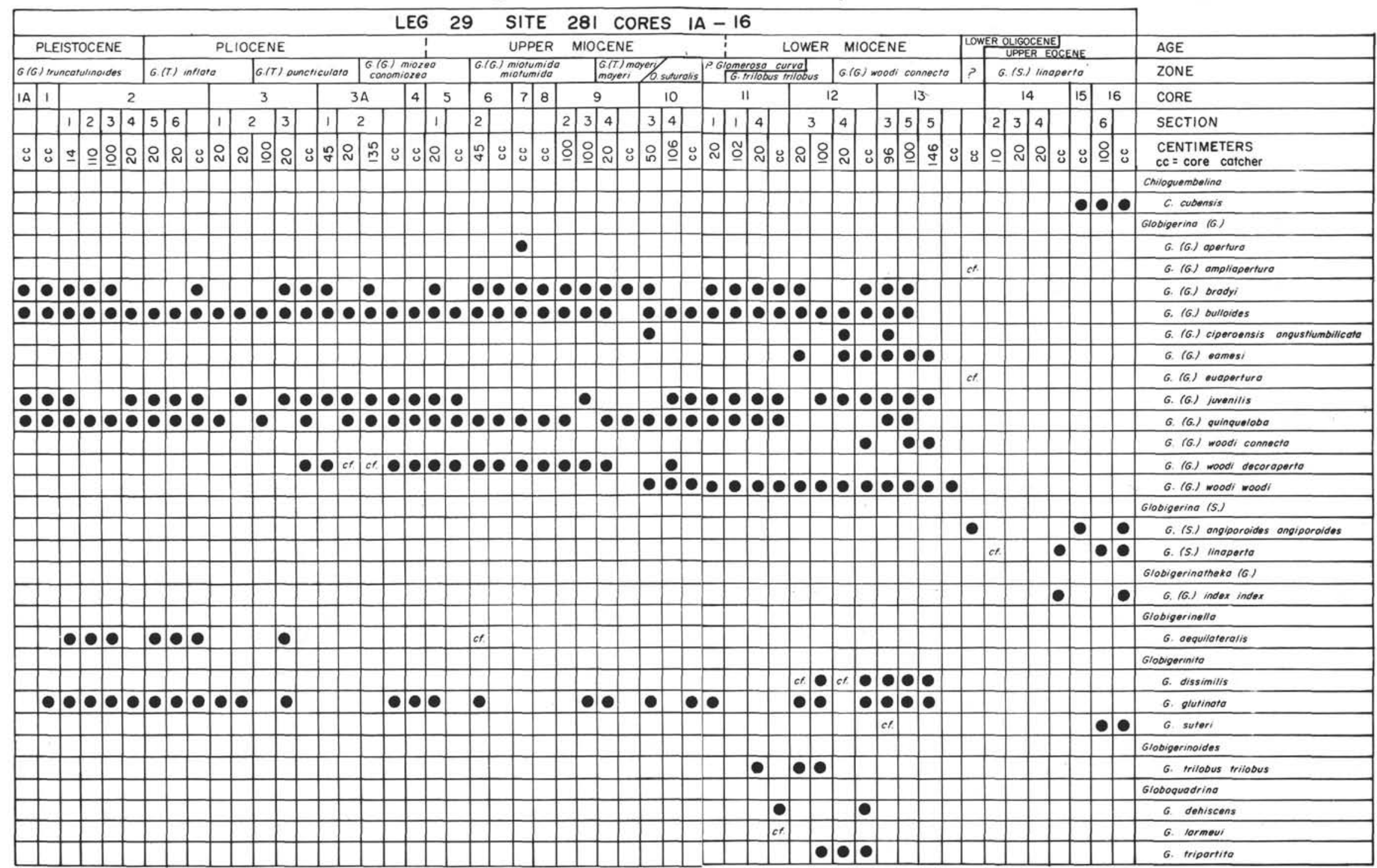


TABLE 4A - Continued

\begin{tabular}{|c|c|c|c|c|c|c|c|c|c|c|c|c|c|c|c|c|c|c|c|c|c|c|c|c|c|c|c|c|c|c|c|c|c|c|c|c|c|c|c|c|c|c|c|c|c|c|c|c|c|}
\hline & & & & & & & & & & & & & & & & & LE & & 29 & & & ITE & & & 1, & 28 & & & $\mathrm{CO}$ & RE & & & -1 & & & & & & & & & & & & & & & & \\
\hline & PLEI & ISTO & CE & & & & & & & & & IOC & ENE & & & & & & & & & & UPP & & & IOC & ENE & & & & & & OWE & & MIO & CEI & & & & & & $\sqrt[\text { LOWER }]{\mathrm{Lu}}$ & $\begin{array}{l}\frac{R O}{R O} \\
\text { UPPPE }\end{array}$ & $\begin{array}{ll}.1600 \\
B-E\end{array}$ & $\begin{array}{l}\text { CENE } \\
\text { ECGEN }\end{array}$ & & & & $\triangle G E$ \\
\hline & ) tru & ncon & whing & ides & & & ) int & floto & & & & 100 & actic & cularo & & & & & & & 616 & mion & $\begin{array}{l}\text { nitut } \\
\text { umic } \\
\text { unic }\end{array}$ & mido & & & $\begin{array}{ll}\operatorname{lom}_{\text {ger }} \\
\text { yeer }\end{array}$ & 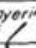 & suture & & & tomer & $\begin{array}{ll}r \text { roso } \\
11000 \mathrm{~s}\end{array}$ & $\frac{c u r t}{t r n}$ & & & $(6)$ & moodi & con & nnecto & & $?$ & & 5) & linaper & & & & ZONE \\
\hline |A & 1 & & & & 2 & & & & & & 3 & & & & $3 A$ & & & 4 & 5 & & 6 & & 7 & 8 & & 9 & & & 10 & & & 11 & & & 1 & 12 & & & & 13 & & & & 14 & 2 & 15 & & 16 & CORE \\
\hline & & 1 & 2 & 3 & 4 & 5 & 6 & & 1 & 2 & & 3 & & 1 & 2 & & & & 1 & 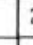 & 2 & & & 2 & 3 & 4 & & 3 & 4 & & 1 & 1 & 4 & & 3 & 4 & & 3 & 5 & 5 & & 2 & 23 & & 4 & & 6 & & SECTION \\
\hline : & $\because$ & I & 의 & 의 & 이 & \begin{tabular}{l|l}
0 \\
N
\end{tabular} & $\stackrel{ }{N}$ & $:$ & ก & 이 & 으 & 은 & $:$ & ช & ㄱ. & 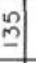 & 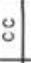 & : & 인 & : & v & : & $:$ & $: \cong$ & 으 & 일 & $\because$ & in & 皇 & $:$ & 이 & $\underline{\tilde{\simeq}}$ & 일 & : & 응 & 요 & $\because$ & $\mathscr{\sigma}$ & 의 & \begin{tabular}{l|}
$\varphi$ \\
$\dot{v}$ \\
\end{tabular} & : & $: 9$ & pi & & $\therefore:$ & : & 의 & $\because$ & $\begin{array}{l}\text { CENTIMETERS } \\
c c=\text { core catcher }\end{array}$ \\
\hline & & & & & & & & & & & & & & & & & & & & & & & & & & & & & & & & & & & & & & & & & & & & & & & & & Globorotalio (G.) \\
\hline & & & & & & & & & & & & & & & & c) & of & & - & 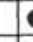 & - $c$ & 4. & - & & & - & & $\bullet$ & & & & & & & & & & & & & & & & & & & & & G. (G.) miotumido miofumido \\
\hline & & & & & & & & & & & & & & & & & • & & c & 6 & - & & - & ? & & & & & & & & & & & & & & & & & & & & & & & & & G. (G) mioreo conoideo \\
\hline & & & & & & & & & & & & & & & & - & 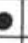 & & - & 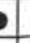 & s. & $f$ & & & & & & & & & & & & & & & & & & & & & & & & & & & G. (G) miozed conomiozeo \\
\hline & & & & & & & & & & & & & & & & & & & & & & & & & & & & & & - & - & - & - & & & & & & & & & & & & & & & & G. (G.) miozeo mioreo \\
\hline & & & & & & & & & & & & & & & & & & of & s & 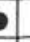 & & & & & & & & & & & & & & & & & & & & & & & & & & & & & G. (G) miozeo sphericomiozeo \\
\hline & & & & & & & & & & & & & & & & & & & & & & c & t. & e & & & & & & & & & & & & & & & & & & & & & & & & & G. (G) pando \\
\hline - & - & - & - & - & - & & & & & & & & & & & & & & & & & & & & & & & & & & & & & & & & & & & & & & & & & & & & G. (G.) Iruncotulinoides \\
\hline & & & & & & & & & & & & & & & & & & & & & & & & & & & & & & & & & & & & & & & & & & & & & & & & & Globorotalio (T.) \\
\hline & & & & & & & & & & & & & & & & & & & - & & & & & & & & & & & & & & & & & & & & & & & & & & & & & & G. (T) se I \\
\hline & & & & & & & & & & & & & & & & & & & & 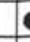 & - & ? & ? & & & & & & & & & & & & & & & & & & & & & & & & & & G. $(\pi$.$) sp 2$ \\
\hline & & & & & & & & & & & & & & & & & & & & & & & & & & & & & & & & & & & & & & & & & & & & & & & & $c t$ & G. (T) aculeato \\
\hline & & & & & & & & & & & & & & & & & & & & & & & & & & & & - & - & - & - & - 0 & of & & & & & & & & & & & & & & & & G. (T.) conice \\
\hline - & & - & - & ot & of & - & - & - & - & - & - & - & - & - & & & & - & . & & & & & & & & & & & & & & & & & & & & & & & & & & & & & & G. (T.) crossoformis \\
\hline & & & & & & & & & & - & - & 는 & & & c) & - & \& & & - & & & & & & & & & & & & & & & & & & & & & & & & & & & & & & G. (T.) crossula \\
\hline & ct & at & & at & & ct. 0 & ct. & & & & & & of & & & & of. & & & & & & & & & & & & & & & & & & & & & & & & & & & & & & & & G. (T.) dutertrei \\
\hline - & - & $\bullet$ & • & $\bullet$ & - & - & - & - & - & - & & & & & & & & & & & & & & & & & & & & & & & & & & & & & & & & & & & & & & & G. (r.) infloto \\
\hline & & & & & & & & & & & & & & & & & & & & & & & & & & & & & & & & & & & & & & & & & & ct & $f: c$ & 6. 0 & ct. $6 t$. & at. & cf. & of. & G. (T.) insolite \\
\hline & & & & & & & & & & & & ct: & ct. & & & & & . & c & & $c$ & & & & & & & & & & & & & & & & & & & $\cdot$ & & & & & & & & & G. (T.) margaritoe \\
\hline & & & & & & & & & & & & & & & & & & & & & & 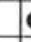 & - & - & $\bullet$ & - & & & & & & & & & & & & & & & & & & & & & & & G. (T.) mayari contimuoso \\
\hline & & & & & & & & & & & & & & & & & & & & & & & & & & - & $\bullet$ & & & & & & & & & & & & & & & & & & & & & & G. (T.) mayeri mayari \\
\hline & & & & & & & & & & & & & & & & & & & & & & & & - & - & $\bullet$ & & & & & & & & & & & & & & & & & & & & & & & G. (T.) mayeri nympho \\
\hline & & & & & & & & & & & & & & & & & & & & & & & & & & & of & ct & & & & of & cf. & - & & $\bullet$ & $\bullet$ & & $\bullet$ & & & & & & & & 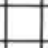 & & G. $(\pi)^{\prime}$ minutissimo \\
\hline & & & & & & & & & & & & & & & & & & & & & & & & & & & & & & & & & & & & & & & & & & & & & & & - & - & G. (T.) nano nano \\
\hline & & & & & & & & & & & & & & & & & & & & & & & & & & & & & & & & & & - & $\bullet$ & - & $\bullet$ & & - & - & & & & & & & & & G. (T) nano eseudocontinuoso \\
\hline - & & & - & $\bullet$ & - & & & & & & & - & & & & & & & & & & & & & & & & & - & & & & & & & & & & & & & & & & & & & & G. (T.) obeso \\
\hline - & - & - & & $\bullet$ & - & - & - & - & - & - & - & - & & - & - & - & - & - & 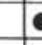 & C & - & & ? & & & & & & & & & & & 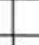 & & & & & & & & & & & & & & & G. $(\pi)$ pochyderma \\
\hline & & & & & & & & & & & & & & & & & & & & & & & & & & & & & $\bullet$ & & - & $\bullet$ & -1 & - & - & - & $\bullet$ & & - & - & & & & & & & & & G. (T.) proescitula \\
\hline & & & & & & - & - & - & - & - & - & - & - & - & $\bullet$ & - & - & - & & & & & & & & & & & & & & & & & & & & & & & & & & & & & & & G. (T.) puncticulato \\
\hline - & - & - & 본 & & $\bullet$ & - & - & - & - & - & & & $\bullet$ & - & & & e & 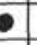 & 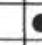 & & ct. & & 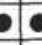 & - a & $\bullet$ & - & - & & & & & & & & & & & & & & & & & & & & & & G. $(T$ ) scifulo \\
\hline & & & & & & & & & & & & & & & & & & & & & & & & & & & & & & & & & $\bullet$ & - & & & & & & & & & & & & & & & G. (T.) zeolandica \\
\hline & & & & & & & & & & & & & & & & & & & & & & & & & & & & & & & & & & & & & & & & & & & & & & & & & Globorotaloides \\
\hline & & & & & & & & & & & & & & & & & & & & & & & & & & & & & & & & & & & & & & & & & & & & & & & & & 6. suteri \\
\hline & & & & & & & & & & & & & & & & & & & & & & & & & & & & & & & & & & & & & & & & & & & & & & & & & 6. Tostarugosa \\
\hline
\end{tabular}


TABLE 4B

Ranges of Planktonic Foraminifera in Selected Samples of Hole 281A

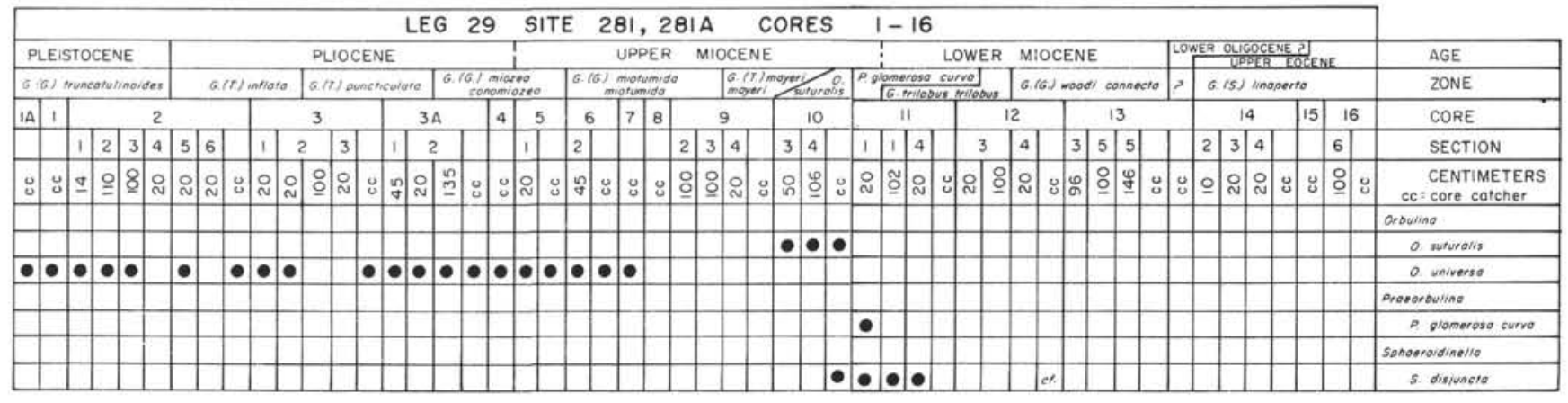

\section{G. (T.) mayeri continuosa Blow}

It is present at Sites 279,280,281, and 284, and at Sites 279, 280 and 281 , it is clearly related to $G$. (T.) mayeri mayeri. A transitional form between $G$. (T.) mayeri continuosa and $G$. (T.) pachyderma exists at Site 281 in the $G$. (G.) miotumida miotumida Zone, as previously reported from New Zealand (Jenkins, 1971).

\section{G. (T.) mayeri mayeri Cushman and Ellisor}

It is a common species within its zone at Sites 279, 280, and 281, and at Sites 279 and $281, G$. (T.) mayeri mayeri is cryptogenic, appearing without its immediate ancestor $G$. (T.) mayeri peripheroronda. $G$. (T.) mayeri mayeri appears to have a tough, solution-resistant test.

\section{G. (T.) mayeri nympha Jenkins}

In New Zealand it became extinct in the upper part of the $G$. (T.) mayeri mayeri Zone, but at Site 281 it survived into the lower part of the succeeding $G$. (G.) miotumida miotumida Zone.

\section{G. (T.) minutissima Bolli}

It is a common form in the $G$. (G.) woodi connecta- $G$. trilobus trilobus zones at Site 279 where specimens have an aperture which is slightly larger than illustrated for the holotype from Trinidad.

\section{G. (T.) munda Jenkins}

At Site 277 there is some evidence that it may have evolved from $G$. (T.) gemma. G. (T.) munda has a juvenile form with regular chambers, but with a higher arched aperture than $G$. $(T$.) gemma. It is possible that $G$. (T.) gemma evolved into $G$. (T.) munda by increasing the test size, with a concomitant increase in the height of the aperture.

\section{G. (T.) nana nana Bolli}

It is fairly rare at Sites 277 and 279 , but was found to be a useful marker in the upper Eocene at Site 282.

\section{G. (T.) nana pseudocontinuosa Jenkins}

It is fairly common at certain intervals in the $G$. (G.) woodi connectaG. trilobus trilobus zones at Site 279; it is much more common at Sites 281 and 282.

\section{G. (T.) nana semivera (Hornibrook)}

It is fairly rare in the $G$. (G.) woodi connecta-G. trilobus trilobus zones at Site 279, with only a few specimens at Site 281.

\section{G. (T.) pachyderma (Ehrenberg)}

Dominantly sinistrally coiled specimens were found in a foraminiferal sand injected into (?)Upper Cretaceous-Paleocene sediment at Site 275. Also sinistrally coiled forms were found at Site 278 in the upper Miocene-Pleistocene, where the robust tests have survived solution effects, resulting in depleted faunas. $G$. (T.) pachyderma occurs in fairly large numbers in the Pleistocene-Recent at Site 279, but is rare at Site 280. A good record of the taxon occurs in the upper Miocene-Pleistocene at Site 281 where the populations are mainly sinistral, but there are both sinistral and dextral populations at Site 284.

\section{G. (T.) praescitula Blow}

There is a good record of $G$. (T.) praescitula at Site 279 from the $G$. (G.) woodi connecta Zone through to the $G$. (T.) mayeri mayeri Zone, but it is very rare at its cryptogenic initial appearance.

\section{G. (T.) puncticulata (Deshayes;}

A sample at Site 276 yielded specimens of $G$. (T.) puncticulata with distinctly angled peripheral margins. Its presence at Site 278 in very deep-water sediments suggests that it has a relatively strong solutionresistant test. Good faunas of $G$. (T.) puncticulata were obtained from Sites 281 and 284. At Site 284 there could be a transition between it and $G$. $(G$.) miozea sphericomiozea in the $G$. (G.) miozea conomiozea Zone.

\section{G. (T.) scitula (Brady)}

Very rare specimens were recorded in the $G$. (T.) puncticulata Zone at Site 278 and in the G. (G.) truncatulinoides zone at Site 279. G. (T.) scitula is much more common in the Miocene-Pleistocene $G$. (T.) mayeri mayeri-G. (G.) truncatulinoides zones at Sites 281 and 284.

\section{G. (T.) tosaensis Takayanagi and Saito}

Morphotypes of $G$. (T.) tosaensis exist in the Pleistocene G. (G.) truncatulinoides populations at Site 284.

\section{G. (T.) zealandica Hornibrook}

It is very rare in the lower Miocene G. trilobus trilobus Zone at Site 279 but numbers increase in the middle of the zone where it is quite common. From its range in southeast Australia (Jenkins, 1960) and New Zealand (Jenkins, 1971) G. (T.) zealandica is considered to be a good marker for the G. trilobus trilobus Zone.

\section{Globorotaloides extans (Jenkins)}

Typical specimens were obtained from the $G$. (G.) euapertura Zone at Site 282.

\section{G. turgida (Finlay)}

At Site $277 G$. turgida was very rare in the $P$. primitiva-G. $(T$.) aculeata zones compared with its normal relative abundance in the Paleocene-Eocene of New Zealand.

\section{G. testarugosa (Jenkins)}

It was found to be common in the upper $G$. (S.) angiporoides angiporoides-G. (G.) euapertura zones at Site 277.

\section{G. suteri Bolli}

At Site 277 G. suteri appears to evolve into the coarser walled $G$. testarugosa in the upper part of the $G$. (S.) angiporoides angiporoides Zone. 
TABLE 5

Ranges of Planktonic Foraminifera in Selected Samples of Site 282

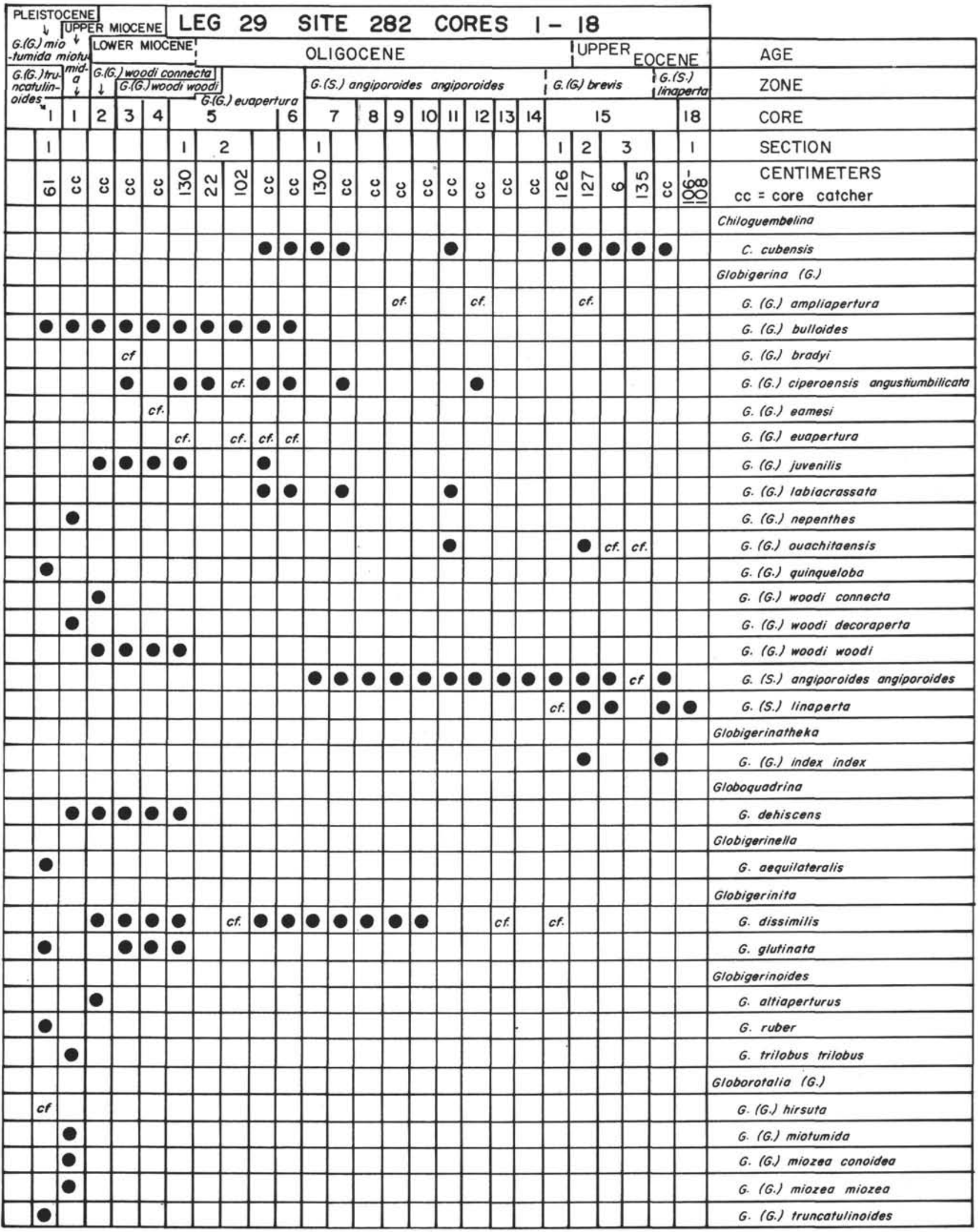


TABLE 5 - Continued

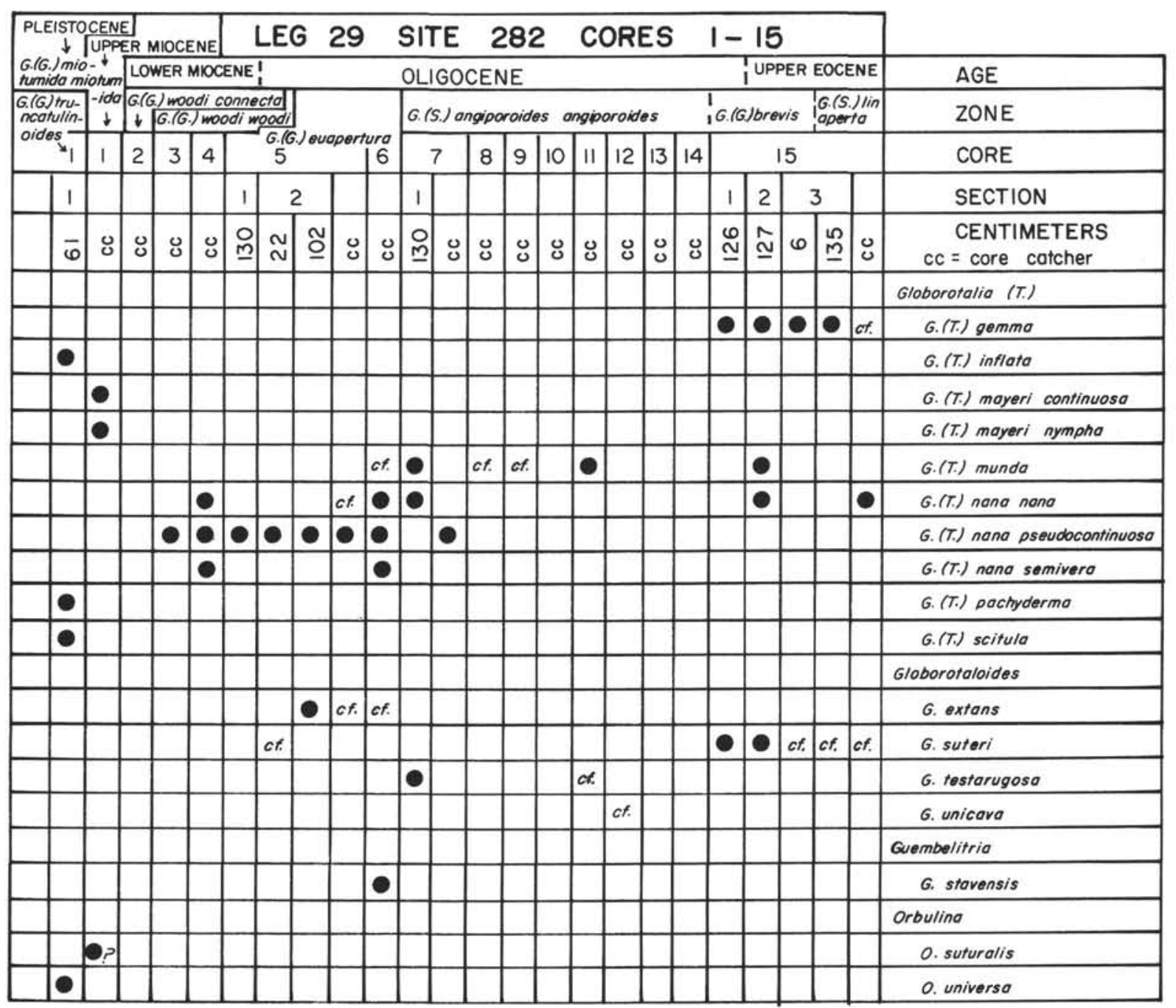

\section{Guembelitria stavensis Bandy}

At both Sites 277 and 282 G. stavensis was found in well-developed faunas of the $G$. (G.) enapertura Zone. It is also suggested that a bitsample obtained from Site 276 with a few specimens of $G$. stavensis is also from the $G$. (G.) euapertura zone.

\section{Orbulina suturalis Bronnimann}

Rare specimens were obtained from the $G$. (T.) mayeri mayeri Zone at Sites 279 and 280 , and typical specimens from the $O$. suturalis Zone at Site 281 .

\section{O. universa d'Orbigny}

Only a few small specimens were recovered from the Pleistocene of the southern Sites 275, 279, 281, and 282, but it is quite common in the G. (G.) miotumida miotumida-G. (G.) truncatulinoides zones of Site 284 .

\section{Praeorbulina glomerosa curva (Blow)}

A few specimens were obtained from the zone of the same name at Sites 279 and 281. The lack of its descendant taxa $P$. glomerosa glomerosa and $P$. glomerosa circularis at these sites suggests that it penetrated further south than its descendants.

\section{Pseudogloboquadrina primitiva (Finlay)}

At Site 277 it was recorded from the Paleocene G. (S.) triloculinoides Zone to the upper Eocene $G$. (T.) aculeata Zone.
Truncorotaloides collactea (Finlay)

It was found to be fairly common at Site 277 from the $G$. wilcoxensis Zone to the $G$. (T.) aculeata Zone.

\section{Zeauvigerina Finlay}

The three New Zealand species, Z. parri, Z. teuria, and Z. zelandica, were recorded in the Paleocene-Eocene rocks at Site 277.

\section{REFERENCES}

Jenkins, D. G., 1960. Planktonic foraminifera from the Lakes Entrance oil shaft, Victoria, Australia: Micropaleontology, v. 6 , p. 345 .

1966. Planktonic foraminiferal zones and new taxa from the Danian to Lower Miocene of New Zealand: New Zealand J. Geol. Geophys., v. 8, p. 1088 .

1967. Planktonic foraminiferal zones and new taxa from the lower Miocene to the Pleistocene: New Zealand J. Geol. Geophys., v. 10, p. 1064.

1971. New Zealand Cenozoic planktonic foraminifera: New Zealand Geol. Surv. Paleontol. Bull. 42, p. 1278.

Ludbrook, N. and Lindsay, J. M., 1969. Tertiary foraminiferal zones in South Australia: Plankt. Conf. Microfossils, First, Geneva, 1967, Proc., v. 2, p. 366. 
TABLE 6

Ranges of Planktonic Foraminifera in Selected Samples of Site 284

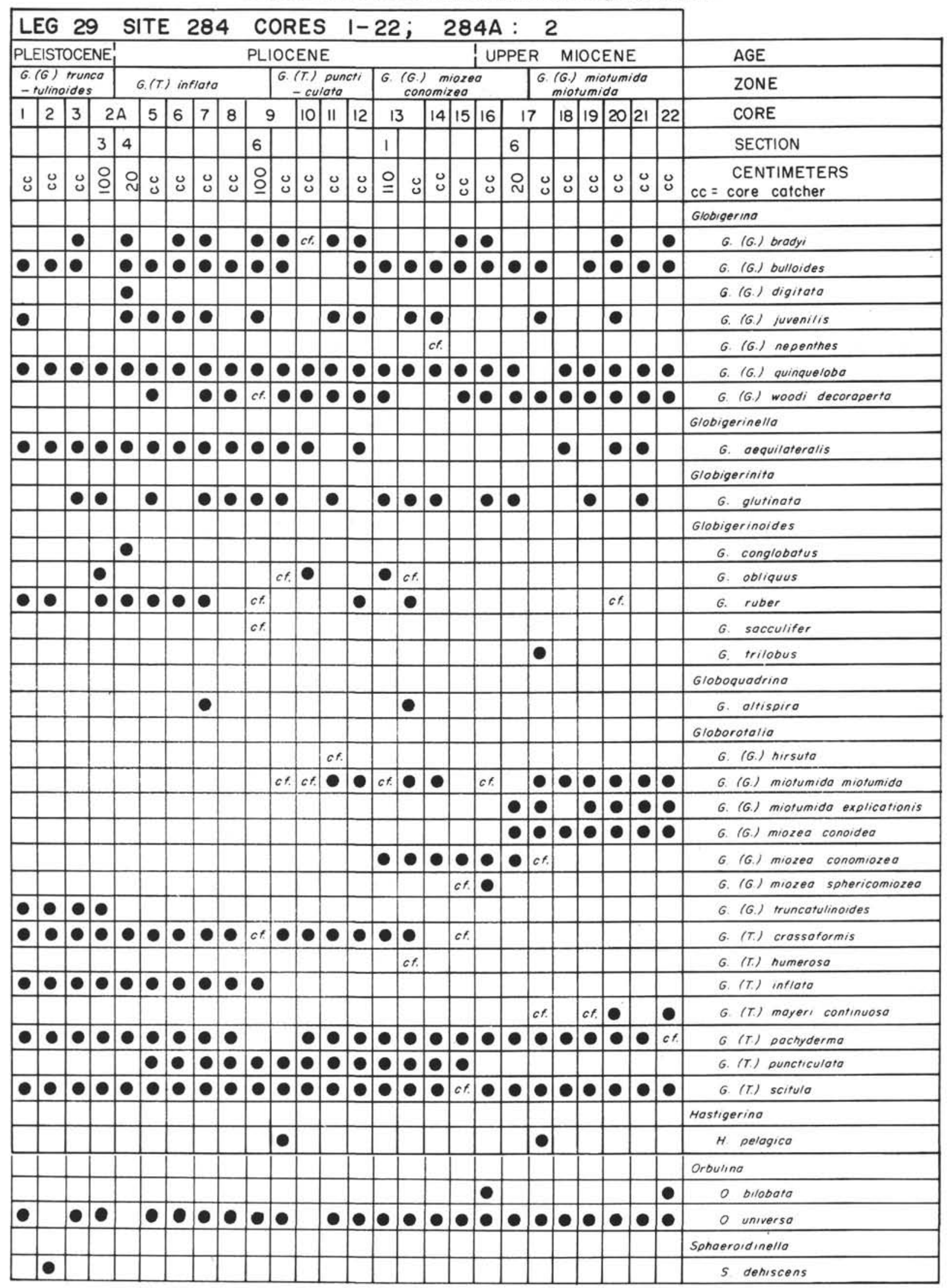


TABLE 7

Correlation of New Zealand Planktonic Foraminiferal Zones and Zones Used on Leg 29

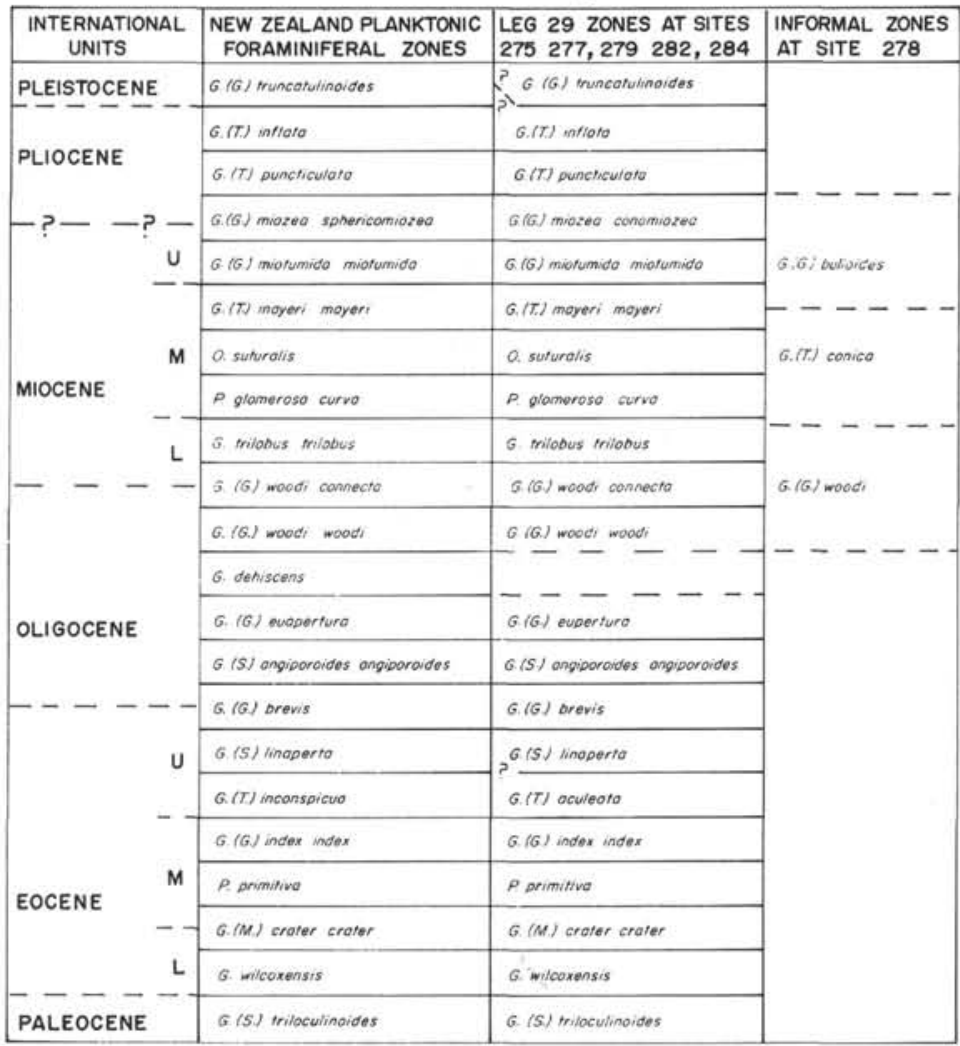

TABLE 8

Pianktonic Foraminiferal Zones Used on Leg 29 and Taxa Used to Delineate the Zonal Boundaries

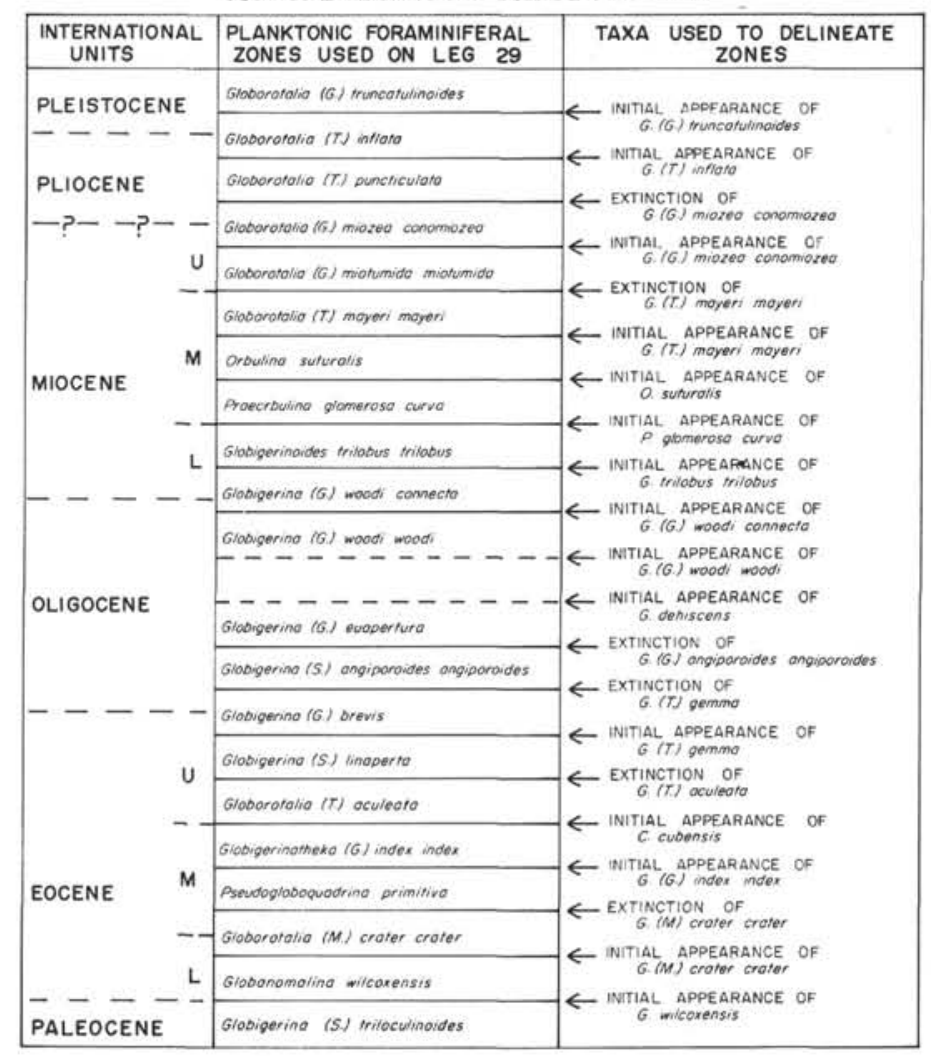


TABLE 9

Planktonic Foraminiferal Zones Penetrated at Sites Drilled on Leg 29

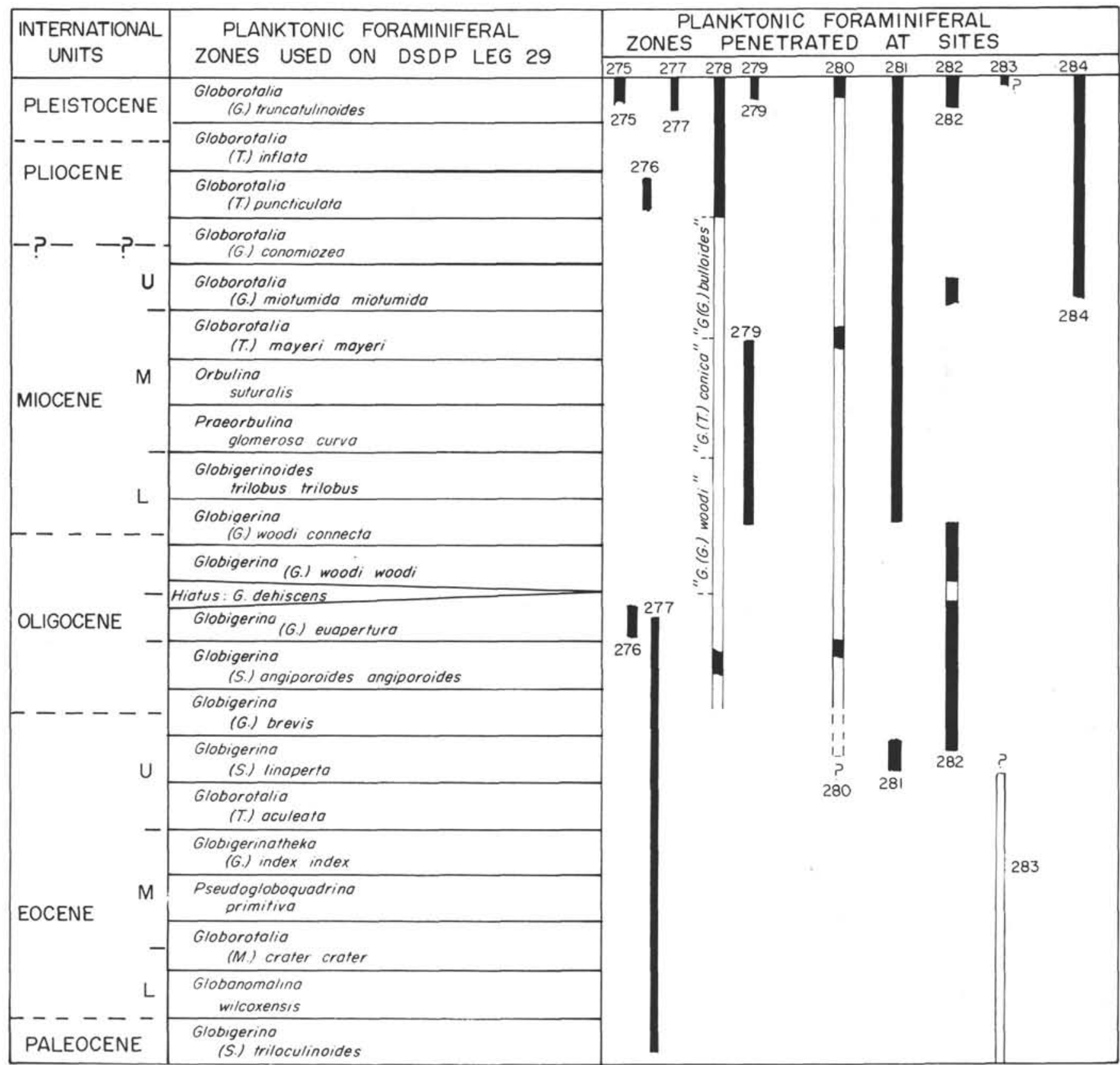

